\title{
Youth in the Arab World: Their Aspirations and Identities with Democracy in Egypt
}

Shubhda CHAUDHARY

PhD from Jawaharlal Nehru University, India.

shubhda.chaudhary@gmail.com

Recibido: 26/10/2015. Revisado y aprobado para publicación : 14/12/2015

Para citar este artículo: Shubhda Chaudhary, Youth in the Arab World: Their Aspirations and Identities with

Democracy in Egypt, Revista de Estudios Internacionales Mediterráneos, 19, 113-126

Para acceder a este artículo: http://dx.doi.org/10.15366/reim2015.19.007

\begin{abstract}
After Mohamed Bouazizi set himself on fire on December 17, 2010, the world attention was caught by pro-democracy protests, starting from Tunisia, Egypt, and other parts of Middle East and North Africa. The major protagonists in this entire outburst were youth. Thus, this paper tries to understand what the Egyptian Youth actually means by "democracy", what impact does it have for them and how do they want to play a pivotal role in the nation-building process, in spite of the fact that they do not have the means to. Digging deeper, the paper tries to reveal the identities and interests of the Egyptian youth, hailing from different segments of the society and trying to understand the major hindrances they face while they demand for democracy, trying to meticulously scrutinize the reasons, processes and the consequences of it. The research paper adopted a methodology that used a deliberative assembly of 50 participants from Egyptian youth, as a preliminary research technique to explore people's ideas and attitudes. After that, 50 young people responded to an E-mail survey carried out in August and September 2015.
\end{abstract}

\section{Keywords:}

Youth, Arab democracy, Citizenship, Uprisings, Egypt. 


\section{Resumen:}

Después de que Mohamed Bouazizi se prendiese fuego el 17 de diciembre de 2010, el mundo fue cautivado por las protestas pro-democracia, que partieron de Túnez, pasando por Egipto y otras partes de Oriente Medio y el Norte de África. Los principales protagonistas de toda esta explosión contestataria eran jóvenes. Así, este trabajo trata de entender lo que la juventud egipcia entiende realmente por "democracia", ¿qué impacto podría tener para ellos? y ¿cómo creen que pueden jugar un papel fundamental en el proceso de construcción de la nación?, a sabiendas de que probablemente no disponen de los medios para ello. Indagando más en profundidad, el trabajo trata de revelar las identidades y los intereses de la juventud egipcia, contando para ello con individuos procedentes de diferentes sectores de la sociedad. Intenta también entender los principales obstáculos a los que se enfrentan los jóvenes cuando reivindican la democracia al tiempo que examina las razones, los procesos y las consecuencias de la misma. El trabajo de investigación adoptó una metodología que utilizó una asamblea deliberativa de 50 participantes egipcios. Esta técnica de investigación preliminar permitió explorar ideas y actitudes de las jóvenes personas participantes. Luego, 50 jóvenes respondieron a una encuesta por correo electrónico que se llevó a cabo en agosto y septiembre de 2015.

\section{Palabras claves:}

Jóvenes, ciudadanía, democracia árabe, sublevación, Egipto.

\section{Introduction}

For decades, several scholars have pointed out that the increasing youth bulge in Middle Eastern countries is a worrisome fact, taking into acknowledgement the rising growth of unemployment and low standards of living. Scholars like Stephanie Schwartz (2011) have pointed out the 'violent potential of youth' who have little access to employment opportunities in their country and additionally, their grievances are not being met by the political governance of their respective countries. Though interestingly, this has led to growth in the number of youth activists who are though, not joining the rebel movements, but is finding new, nascent ways of describing their grievances. Most of which include low wages, high food prices and low employment standards. The global interconnectivity, endowed by emerging platforms of social media have further aided in consolidating the fragmented voices, helping them to mobilize movements which have helped in voicing their speech and expression, in a manner which was not fathomed before in these countries like Tunisia, Egypt, Bahrain, Syria and others (Dabashi, 2012). Talking about the 'Demographics of Arab Protests' Ragui Assaad (2011) states that the region is currently facing a demographic bulge in which the youth, aged between 15 to 29 years of age, comprise the largest part of the population. He also compares the 'youth bulge' in other countries of South East Asia and East Asia and describes how the good education systems and open economies had witnessed this phenomenon as an opportunity rather than challenge. In countries like Egypt, which is at the peak of its 'youth bulge', the demographics includes a large number of youth who are very frustrated at their inability to transform their education into productive and well-paying jobs, which has eventually exacerbated the situation (Hoffman \& Amaney, 2012). In the context of what is happening in this region, scholars like Hamid Dabashi (2012), have mentioned how the world is running out of metaphors and in this process, they are crafting new identities and at the same time, forging new solidarities, which are both within and without the "Islam and the West" binary. 
Hence, they are overcoming once and for all the thick (material and moral) colonial divide which had always existed in analyzing this region. At the same time, it needs to be kept in mind that not all cohorts of teenagers and youth produce movements which are centered around their identity, accompanied by a set of organizational symbols and demands. Thus, what Juan Cole (2014) calls the 'New Arabs', have the potential to forever change their societies. The regimented and patriarchal culture of the Arab society has also played a pivotal role in these causing these movements to stand apart. These networked youth communities rejected police brutality, arbitrary arrests, dynastic succession and torture, which for years had failed to unite them. Thus, the youth movements, especially in Egypt, developed a new concept of personal freedom, which laid more emphasis on the autonomy and dignity of the citizens ${ }^{1}$. Though, it still needs to be kept in mind that when these movements did spread, be it in 2011 against Hosni Mubarak or in 2013 against Mohamed Morsi, they honestly had partial success. In the case of 2011 protests against Hosni Mubarak, the uprisings were hijacked by Muslim Brotherhood because they had better networking and had developed as a grassroots movement for decades, while in the case of disposing Morsi in 2013, the police and army played a pivotal role in endowing the strength and the ability to cause 'violence'. What must be kept in mind is that in both the cases of uprising, the youth were leaderless, in spite of their burgeoning number. Also, they had very limited understanding of the kind of vision, in terms of governance and political legitimacy, which would eventually take place after the uprisings have won the power struggle. Though, what they did do, and are still doing, is creating virtual public spheres to consolidate and vent out their frustration through the social media platforms, a phenomenon which had never taken place before.

This research paper aims to bring out the fact that the youth in Egypt have been sidelined in spite of playing a pivotal role in mobilizing the uprisings against Hosni Mubarak in 2011. The research paper adopted a methodology that ensured that all the popular and general genres of employment are chosen, so that greater space of engagement and debate can be endowed to the population. The research used a deliberative assembly as a preliminary research technique to explore people's ideas and attitudes. This assembly mainly comprised of 50 participants from Egyptian youth, from the age-group of 19-30 years. The demographic profile of the assembly was heterogeneous and it included participants from journalism, academics, law, film-making, medicine and engineering sectors of employment. The questionnaires included six open-ended questions. Open-ended questions are questions without explicit response choices so that the respondents provide their own answers in their own words. The E-mail surveys were sent as messages to respondents' e-mail addresses. 50 respondents then marked their answers in the message and send them back to the researcher. The survey was carried out in the month of August and September 2015. The following questions were asked to these interviewees:

1. What is Arab democracy according to you?

2. Why are the Arab youth protesting?

3. Has Arab Spring failed?

4. Do you think Arab Youth has been sidelined from the protests?

5. Why have the youth been sidelined in your country?

6. Can the Arab Youth play an important part in nation building?

All these questions are descriptive and analytical in nature, trying to figure out the current consensus among the youth.

\footnotetext{
${ }^{1}$ On these trends in other countries affected by the mobilizations of 2011, we refer to Murphy (2012) and Desrues (2012 and 2013a) and Desrues and Kirhlani (2013b).
} 


\section{Youth Population in the Arab World and Egypt}

The regional overview of Youth in Arab region states that out of 22 countries in the Arab region, only nine countries have either developed youth policies or are in the process of formulating them. Sixty percent of the region's people are under 30, twice the percent of North America. ${ }^{2}$ Adding to that, North Africa and the Middle East have the highest regional rates of joblessness in the world (Knickmeyer, 2011). Also, about 500,000 additional people in MENA are unemployed each year (Raphaeli, 2006). The youth bulge in the Arab world has become even more pronounced due to the lack of employment opportunities, as narrated by Isobel Coleman through the below mentioned chart (Coleman, 2013).

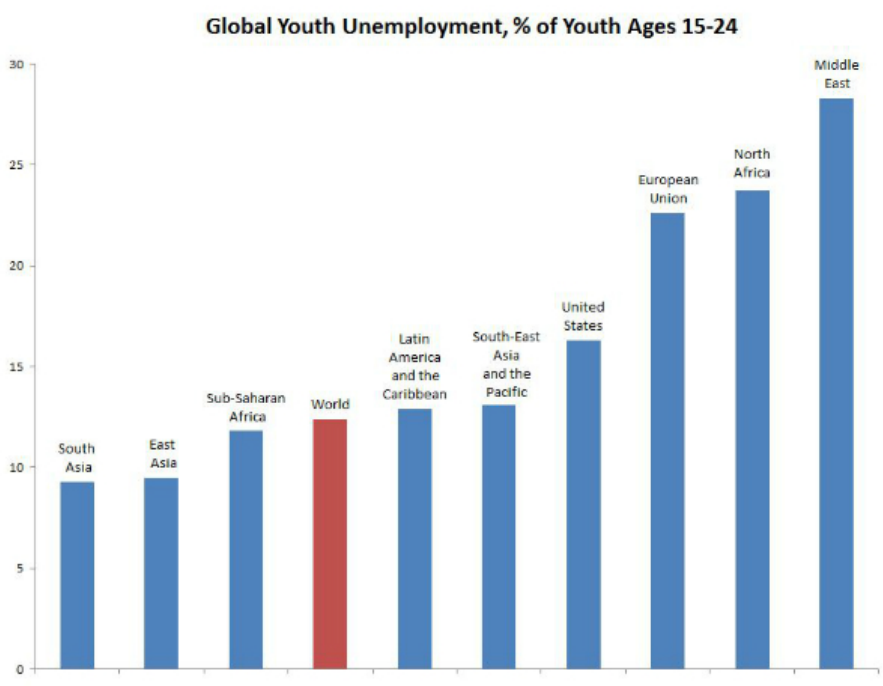

Thus, policy makers have to keep in mind that national youth policies and action plans need to be formulated, which play an integral role in the human capital development, along with helping the youth reach out to their full potential. Barry Mirkin (2013) in his contribution to The Arab Human Development Report, clearly stated:

"The reduction of high fertility and increases in the working-age population can create opportunities for economic growth if the right mix of educational, health, and labor-market policies are in place. For Arab countries to reap the benefit from this "demographic dividend", employment generation must keep pace with the large number of job seekers, which has not been the case in the recent past."

Seiko Sugita, Programme Specialist in Social and Human Sciences, UNESCO Beirut states that the youth includes young men and women who are aged between 15 to 24 years, and are currently living in both rural and urban settings. Some of these youth members also suffer from sickness and disabilities. While, others also fall in the bracket of migrants, minorities, stateless and refugees and internally displaced (Sugita, 2011).

Thus, it needs to be understood that alongside with the rise of unemployment, the youth of the Arab world is also frustrated with the kind of political set-up in their countries. The dynamic youth

\footnotetext{
${ }^{2}$ See Pew Forum on Religion and Public Life, 2011, "The Future of the Global Muslim Population: Projections for 20102030." http://www.pewforum.org/2011/01/27/the-future-of-the-global-muslim-population/ 
population feels dominated due to the strict laws curbing their freedom of speech and expression. For a very long time, the youth has not been able to openly vent out their political and social opinions as they are scared of the repression in the military regimes. At the same time, the way the uprisings in the Arab world unfolded, it was noticed that the youth who were participating in the demonstrations were less religious, more secular and liberal in their ideologies. Ellen Knickmeyer (2011) reports that youth who participated in the uprisings were not bearded Islamists or jaded leftists. A study by Population Action International revealed that almost 80 percent of the world's conflicts especially between 1970 and 1999 started in countries where 60 percent of the population was under 30. John Esposito (2011), who has also written a book recently on the 'future of Islam' states that:

"The signs, placards, statements, demands and the waving of flags not Islamist placards indicated, protesters want to reclaim their dignity, control of their lives and the right to determine their government; they demand government accountability and transparency, rule of law, an end to widespread corruption, and respect for human rights."

Thus, the tides are turning in the Arab world, especially because of the youth who have new notions of political governance and legitimacy. They are craving to form their new identities, which are not shackled by the repressive regimes, thereby giving a chance for concepts like 'Arab Democracy' to grow. Though, they have the political understanding and engagement on social media platforms to have their opinions regarding the kind of democracy they want, one needs to also understand that the youth of the Arab world lacks direction and a consensus amongst themselves because of being too fragmented and engaged with several different ideas. It is very difficult thus, for them, to have a clear cut definition of even what Arab democracy means and what are its limitations, if any. The kind of intellectual voice that should arise from the region which takes into account different political theories, their own cultural history and grievances to have engagement in the international platforms through literature and surveys is currently missing and thus, it becomes very difficult to understand what the youth of the Arab world really wants.

With a population of 81 million, Egypt is the most populous country in the Middle East. Young people aged 15-29 make up one-third of the country's total population about 23 million. Unemployment among the youth soared, reaching 24\% by December 2010 (World Bank, 2010).

The youth movements in Egypt played a pivotal role in mobilizing the uprising against the Egyptian ruler Hosni Mubarak in 2011, ultimately leading to his downfall. It must be kept in mind that the trend of youth movements in Egypt cannot be isolated to 2011 only, as the movements like Kefaya and April 6 had been present long before. Most of these youth movements had also been, for a long time, asking for transformation in the government policies of the country, which had heavy repression and military rule that curbed their freedom of speech and expression. For example, the Kefaya-also known as the Egyptian Movement for Change-had slowly developed out of mass discontent when Mubarak bid for $5^{\text {th }}$ six-year term in 2005. It had gained massive leverage and attention, and from that time onwards, the pertinent need of Arab democracy was felt by the Egyptian youth. But the movement ultimately declined in its potential and faltered due to the rise in media media-oppostion and the control of the government. But at the same time, scholars like Ben Marcus (2012) believe that this movement played a significant role in endowing the choice to the Egyptian youth to vent out their frustration against the government. The April 6th Youth, named for its call for a general strike on April 6, 2008, represented young Egyptians of varying 
political orientations and was the first opposition group to make use of Facebook (April 6th Youth, 2011) (Lim, 2012). ${ }^{3}$

Jawad Nabuls, CEO and co-founder of the Nebny Foundation in Egypt, talks about how it is very important for the Egyptian to be ready with solutions, especially when there is a crisis in governance, along with mobilizing the protests. This is one tendency which lacks in the Egyptian youth as they fail to the needed solutions which either aim at systemic or constitutional reforms (Nabulsi, 2013). Thus, the toughest challenge for the upcoming youth movements in Egypt is definitely the manner in which they develop institutionalized means of political participation, which has been lacking in the earlier protests. This phenomenon is very crucial for societies that are undergoing crucial change. The lack of well structured civil societies and institutions, especially during the transition phase to democracy is also another major impediment. Also, the youth movements need to know the trajectories of involving the broader segments of the society, be it, the journalists, academicians, lawyers, peasant unions, NGOs and other public sector officers (Monshipouri, 2014).

\section{Youth's Aspirations from Arab Spring in Egypt}

After this brief presentation of the demographic weight that represents youth in the Arab world and Egypt, and the theoretical implications that this weight may have on future political developments in the region, we will discuss various topics related to democracy, opposition and the role of youth.

\section{What is Arab democracy according to you?}

Most of the interviewees believed that Arab democracy did not exist and it was an 'expression on the paper'. Though, few believed that the conditions were not so morose, though, it might just be tougher to realize given the long old heritage of political dictatorship and religious backwardness. While, other believed that Tunisia was the only country in Middle East which had Arab democracy. The need for Trading Authority, freedom, human rights, anti-Corruption, Economic development was also felt by the participants. For others, it was an act, as in people say "we believe in it and seek for it but when it comes to making real life changing choices the fear of the unknown or the uncontrolled change holds them back." The level of fear can also be figured out from the responses of the participants who believed that Arab democracy was the freedom of speech and saying your opinion without being arrested, and it's the right to have the minimum requirements for a good living. While, few noted that Arab democracy is like democracy anywhere else, a social contract determining the peaceful transition of power where the people, not the state, have the upper hand in deciding how their countries should be governed. It implies equality, freedom, and justice, fair implementation of law without discrimination, preserving human rights, free civil society, free press and independent judiciary. This would never be implemented without accountability of those in power, whose authorities, powers; finances are all brought under the mentorship of the people. Arab democracy would exist, when people in Arab countries have the freedom to choose their representatives in the government and legislative councils through fair elections. While, few participants pointed on the importance of elections, like the ability to choose

\footnotetext{
${ }^{3}$ Facebook, 2008, April 6 Youth Movement, https://www.facebook.com/April-6-Youth-Movement-199378773499996/
} 
government officials freely from the post of President of the Republic and even the mayor, and equitable distribution of wealth.'. At the same time, there were others who had a very pessimistic view of Arab democracy or democracy as a concept in totality. They called it an illusion and no one in the Middle East had any real interest in allowing any of the populations to have a real say in their governments. On the other hand, they did not actually believe that there are very many real democracies anywhere in the world. While few believed that there is no particular concept as 'Arab democracy' in general and this distinction should not be made. Rather, it is just democracy that should be focused which takes human rights into account. Democracy is beyond electoral processes, it entails peoples' inclusion in decision-making, and the full transparency. It is a must that any democratic structure allows for freedom of expression and full freedoms, especially the right to association and organizes, all of which are still absent from Arab contexts. Many still believed in the slogan of 'bread, freedom and social justice' as the meaning of Arab democracy while others found the question to be quite ambiguous, as the culture and geography cannot make the distinction between the types of democracy. At the same time, there were few radical views of defining Arab democracy as "ISIS and Muslim Brotherhood' which definitely make an interesting debate. Arab countries have been considered exception for the whole world as the concept of democracy did not pass by its region. However, the past four years had proved that people want democracy as they were suppressed for years. So, democracy in the Arab world is surely is possible. The question is: 1- How much will it take for the countries to be democratic? 2The tyrants' consequences on the democratic transition process? Democracy as a notion is western in essence. Few participants do not believe there is such a thing as an "Arab" democracy; it is democracy per se. We can define it the same way it is defined elsewhere depending on the existence of certain indicators including: Party pluralism; high turn-out; women political empowerment; human rights; status of prisons and so on. In a nutshell, the voices of the youth regarding to the question of Arab democracy are well informed and entailing a particular thought process, which reveals that they have spent consistent amount of time in dealing with this concept, understanding what it means for their region and its consequences. Though, even if it might be an 'illusion' or in some cases a 'dream', none of the participants had a negative view regarding the concept of Arab Democracy which in itself is quite empowering as a result.

\section{Why are the Arab youth protesting?}

The interviewees had very interesting and long ranging answers to this question of the need of protests and what kind of grievances this community particularly had. They protested in the participant's opinion because they perceived a chance to follow a wave of dissent that represented what they already dealt with but were apathetic enough to choose to live with it. Few believe the economic motive was also stronger than the political in this case. For others, they are fed up by the injustice, corruption and poverty. For example, Egypt the main three slogans were: Break, Freedom and social justice. This summarizes the demands and the goals. While few participants had a very pessimistic view and believed that there is no hope in the future, this is still making the youth to protest. Lack of political freedom and social justice are other important aspects of the protest. Others noted the need for better health care and more security for the reason for the protests to take place. Different layers of dissatisfaction, including high unemployment, lack of dignity and rights, exclusion from state policy, no transparency, deteriorating standards of living still continue to dominate the scene in Egypt. For few, it was mainly the 'money problem' which was making the youth to strike a discord against the 
governance because they had less employment opportunities. At the same time, others noted that unfortunately, they youth are no longer protesting, because the political sphere has been largely foreclosed. Arab youth are protesting because they are looking for improvement. They are fed up with the politics they are having in their countries, feed up with poverty, with injustice. They are having government who works for the nation instead of working for their own interests. For few participants, the protests are over, as the youth were protesting for very good reasons. Most are unemployed or underemployed, have no voice in their country, very little hope to find work and be able to establish a family that they could hope to support. Few respondents believe that what more Arab citizens suffer in their view are the affront humanity, and physical repression, particularly during his attempts to express his/her opinion, it is the length of time he/she feels boxed police and corrupt, corruption comes in the second phase, financial corruption, administrative corruption, and thus the lack of equality of opportunity, this leads to the presence of the leaders in the wrong places, these corrupt can climb the ladder of wealth and become entrepreneurs and concentrate power in the hands of the gang, they find that the power concentrated in the hands of a gang of political business, and sometimes this gang are dressed military suit. The lack of democracy is another pertinent reason noted and felt by the interviewees. While, the other reasons charted out were that the youth don't enjoy the freedom other countries have, they don't have the resources for a decent life, they face oppression and intolerance in everyday situations from anyone in authority, they are not involved in the decision making process country-wise, and they have lost hope in the government based on their actions. The disappointment in the political systems was quite evident in most of the participants of the interview. Few believe that the current situation has further worsened after the Arab Spring and thus, the youth are not having the right platforms to operate so that they can vent out their frustrations. Nothing has changed after the Arab Spring, it is the same regime with different faces. Few respondents stated that as children they were brought up by families that kept them in a small perfect world were morals are real .And now, growing up to face the real world where they don't exist, the youth does not know what else to do other than try to make that perfect world real as much as they can. Many still revealed the fear that continues to haunt the youth and they believe that any kind of protest is now dangerous because their family life will be disrupted and the chances are they would also be 'kicked out from their jobs'. While, for other participants the reasons of protest were not limited to personal expression but for the greater good of the country and the hope for a better future. Now more than 40,000 youth have been detained because they protested and thus, the slogans for justice, bread and humanity do not serve true, especially in the current repressive regime. Most of the participants still feel that there is a hopelessness regarding the future of the revolution in Egypt, which is now curbing the youth from protesting for their rights.

\section{Has Arab Spring failed?}

At least, $90 \%$ of the respondents said that the Arab Spring has failed. Others believed that no, the fight has just started and gave examples of the French Revolution and the Fight against apartheid, as the longevity of these protests should be taken into account while dealing with sensitive issues like the Arab Spring. For others, the term in itself is limiting. It's neither an Arab Spring or an authoritarian autumn. It is a continuous struggle between agents of progress and agents of despair. Like all historical events, it will take years to reveal its true result. Others stated that they would like to think that it is a snow ball effect starter. It may have not changed everything but they hope that the people with continue the change movement in the Arab world. Though, others who fell into the category of yes and no both, as the Arab Spring did remove the earlier repressive 
regime but it is the aftermath of the Arab Spring that failed. It has failed for the current period, but it has made Arab youth more aware and that will useful for the next period. Freedom in Egypt is the same as before the revolution and even worse. Few participants clearly stated that in my country, the counter-revolution did not succeed. But now judge they have made, youth activists who called for revolution now they are in prisons, General Sisi in Egypt is the worst era of Hosni Mubarak before the revolution.' The Arab Spring was high jacked in Egypt right from the beginning. The army used the people to get rid of the Mubarak sons and then took back the power that they had always wielded. For few, Arab Spring didn't fail. Those countries need time to see the result of their actions. Few respondents clearly stated, 'I don't use the term "Arab Spring," and don't subscribe to the dichotomy of failure/success of revolution. Some Arab uprisings have led to a certain degree of sustainable change (i.e. Tunisia), some have led directly or indirectly to internal political turmoil (i.e. Syria, Yemen, Libya), and some have led to the consolidation of authoritarian regimes (Egypt).' Others stated that the description of spring is really problematic. It implies that it's a seasonal thing, when in fact; it's an evolution/revolution that's passing through different phases. Before the so called Arab Spring, there were a lot of peaceful grass roots movements that were trying to make a difference despite the clamp down. And after the retreat of the spring, we still continue to go through a revolutionary phase. Even if the political aspect is lagging, the revolution has moved to a social level and is inducing change within younger generations. Few respondents were still not open to accept the idea of failure with Arab Spring and they believed that it is still too soon to make a judgment.

\section{Do you think Arab Youth has been sidelined from the protests?}

Most of the respondents did believe that the Arab Youth has been sidelined from the protests. Others believed that the youth was sidelined from any role in leading the transition, but still at the forefront of protesting. Others stated that the youth have not been sidelined in other countries but protesting has its own consequences. While others stated that the youth have not been sidelined from the protests. They were at the center of the protests, the locomotive of the uprisings themselves, but they were sidelined from most of the political processes that ensued. The real power in the country never took the young people seriously and if they were taken seriously they were seriously taken into prison or taken somewhere and beaten to death. While others stated that the youth have participated heavily in the protests and were at the forefront of protests and media. While others answered in affirmative because young demonstrators were arrested as a result of the issuance of laws criminalizing demonstrations. Few stated that in Egypt, protests don't exist and if there is any, youth as individuals -not a part of group like Muslim brotherhood- don't have the chance to participate. At the same time, the notion still exists that it is impossible to sideline millions of people who came out and revolted, especially from the rural areas. Though, they might not be mobilized into masses as before, but they are still fed up by the system. Few stated that it is common knowledge that not all youth know how to participate in protests have the same intentions or level of awareness. Some youth participants are willingly choosing to destroy their future for their present. Few would like to believe that Arab youth are trying to find other tools (in addition to protesting). They're also being hardly cracked down upon by security forces. Many of them are in jail or tired and hopeless. Others are quite optimistic, stating that nobody can ever sideline the youth. But, due to the post-revolt same government measures and suppressive legislation, they try to sideline everyone. 


\section{Why have the youth been sidelined in your country?}

This question can be treated as a media distortion, as many respondents believe that the youth have not been sidelined from the protests but yes, from participating in the political governance in the country. The gap in between the generations is also a big issue, which makes it difficult for the youth to come out in open and participate. The true elements of change take time to evolve but the state is very powerful in the case of Egypt and hence, the youth have been easily sidelined because they do not have so much power to vent out their grievances. Hence, most of the respondents believed that it is the 'power struggle' in Egypt which has sidelined the youth from mobilizing and sharing their opinions and forming demonstrations. The youth of Egypt is demanding justice and most of them have been detained, arrested, tortured or killed which makes it even more difficult for others to participate as the fear of losing one's life is very predominant. Few respondents have also blamed the youth for being sidelined because they chose to be sidelined. They did not have the needed organizational skills and leadership vision which was essential to take Egypt out of the morass of the crisis and hence, the youth leaders lacked experience in governance. In Egypt, the youth, hence are seen as children who do not know what is good or bad for them, thereby giving more power to the regime. Few believed that the youth would be back again, someday, as the conditions right now are quite critical and pose an impediment to the demonstrations. Repression from the state (through repressive laws and security crackdown) and repression by older generation as they failed to understand the youth are also few of the other pertinent factors. They resemble a dangerous threat to the new so-called elected president. Youth are the only group who doesn't get affected by media. Not all of them, but a large group. Other important reason is that youth can have a huge influence on the whole society if they have the chance, and that's what people in authority are afraid of. As the 'State of Elderly' which has returned to govern is afraid of youth movements, they would not let any case like January 25 to take place again. Thus, in a nutshell, everyone in Egypt is sidelined while the military continue to cement power and reassert their economic activities. Because of the entrenchment of ancient-régime institutions that wouldn't allow the youth to take an active part in the political process, the youth are currently facing tremendous pressure. The uprisings were not able to uproot these institutions. While others did state that the youth have been allegedly sidelined because they lack "experience" and knowledge of transition, governance, etc. The youth have been sidelined from the political and social life, because of an intergenerational conflict between the old guard in politics and government that wants to keep its power and young people trying to make their way in society. The youth are being prosecuted for the mere practice of freedom of speech. The current political systems s raging a war against all that was " 25 Jan" under the flag of "war on terrorism" and the number of political detainees and torture is at an all time high. They are unorganized and without vision, and therefore they are weak in front of state institutions such as the army or the business block. They are naive and irresponsible and unprepared for a proper alternative to military rule that excludes religious fundamentalism. There is a law that prohibits protest and hence, all those who did raise their voice are now behind the bars. At the same time, there is apathy. Individual goals are taking over. A belief that despotism is entrenched in the Egyptian state/society is growing stronger.

\section{Can the Arab Youth play an important part in nation building?}

Many respondents clearly stated that theoretically they believe that Arab youth can play an important role in nation building but the practical examples in Tunisia and Egypt, for example, are 
strikingly different. Few still believed that believe that the youth are the ones capable of developing the country and moving it from authoritarian, poor, weak country to strong developed country. If only they are given good quality education and a chance to make a real change. Other respondents revealed an interesting dichotomy that exists in Egypt. On one hand, the 25 Jan revolution has given birth to a generation that is capable of realizing their true potential. On the other hand, the state is adamant to prevent the realization of vision of the widely revolutionary youth since its corner stone is disassembling the vast network of interests that composes and leads the vision of the ruling power. While, others still state that in theory the youth can play a part but when it comes to Egypt, it's only the military which has the real power. But youth should be given a chance because they have a different understanding of the minds, different dreams, after they saw the conclusion reached by young people in developed countries. Currently, they cannot play a pivotal role as they are forbidden to express their opinion freely and trapped from authoritarian power in their own countries, which detains all those who disagree with it. But many of them are in prison or dead right now, so they can't. Most of the Arab population is youth, if their dreams and aspirations are not included in the process, there is no nation building. Youth have new and fresher visions for the future than the more senior people in power. New blood needs to be pumped in the country's backbone. But the high levels of corruption in the country would never endow such power to the youth. Unfortunately, the groups which are closer to the ruling circle have the opportunity and hence, the youth still does not have a voice in Egypt.

\section{Conclusion}

The study clearly shows that the Egyptian youth, who participated in this research, coming from different backgrounds and genres, are tensed and fearful of the future. They have a tussle with the Old Guards and the older generation along with the military which has come into power. The death of many young protestors and their arrest is still fresh in the minds of the youth ${ }^{4}$. But then, most of them do realize that the entire process of Arab democracy cannot be easily attained and it's a time taking process. The realization is there that the political structure has not changed and it's the same regime with different faces. The fear of the repressive military regime is growing and most of the respondents have stated that the so-called Arab Spring has failed.

Thus, it is quite necessary to understand the psychology of the Egyptian youth. They are scared and hence, it creates a major impediment in them attaining a voice, in spite of the fact that they have social media to raise their opinions. Two phenomena have taken place, at the same time in Egypt. On one hand, the social media has endowed freedom of expression to the youth of today, which is more than what they had after the Kefaya and April 6 movement but on the other hand, the amount of fear and uncertainty has also increased because the youth feel that they were not able to replicate the democratic transition that took place in Tunisia. The youth of Egypt is still leaderless and does not have a face, making it even more difficult for them to have a vision regarding the future. They do not know what kind of political governance they would want, if the current military regime is overthrown. Also, they lack experience and hence, they do not understand the politics of the Egyptian state, making them feel powerless and hopeless regarding the future.

\footnotetext{
${ }^{4}$ On the role of repression in other countries affected by the mobilizations of 2011, we refer to Desrues (2013a) for Morocco and Uyçal (2014) for Turkey.
} 
The Old Guards who have come to power now under the Sisi government are making sure that massive protests do not take place in the country. Also, the youth is very fragmented as they do not have the large groups like the trade unions and public officers under their repertoire, thus making them even weaker in front of the state. The conditions are definitely very dismal for the youth of Egypt which is current directionless and hence, it would add a further challenge as Egypt is at the peak of the 'youth bulge' but at the same time, the youth is not seen as 'assets' for the country. It can be predicted that youth of Egypt, who have not given up easily, would find out new tools to harness their potential and to fight back. The only fact that curtails them now is the time, which plays an important role in the case of such transitions. Thus, in the case of Egypt, the concept of Arab democracy would make for an interesting episode, which would definitely be very time taking but at the same time, would test the mettle and spirit of the emerging youth. The youth strongly believes that they have a role to play in the nation building purpose and hence, this trajectory of thought for the greater good for the country and a better future cannot be easily dominated, in the times to come. Thus, with time, the youth protests in Egypt would continue to happen and they would continue to oppose the governance and lack of employment opportunities and low standards of living. It would definitely be too soon to pass a judgment on the Arab youth of Egypt in just four years of the struggle involved, as the protests would continue to unfold in myriad of ways, both political and apolitical in the years to come. 


\section{Bibliography}

ASSAAD, Raggui (2011): "Demographics of Arab Protests," interview with Council on Foreign Relations, 14 February 2011, http://www.cfr.org/egypt/demographics-arab-protests/p24096 [Consulted 13 October 2015].

COLE, Juan (2014): The New Arabs: How the Millennial Generation is Changing the Middle East, New York: Simon \& Schuster.

COLEMAN, Isobel (2013): "Youth Unemployment in the Middle East and North Africa", Council on Foreign Relations, http://blogs.cfr.org/coleman/2013/06/13/youth-unemployment-in-the-middleeast-and-north-africa/ [Consulted 14 August 2015].

DABASHI Hamid (2012): Arab Spring: The End of Postcolonalism, London: Zed Books.

DESRUES, Thierry (2012): "Moroccan Youth and the Forming of a New Generation: Social Change, Collective Action and Political Activism", Mediterranean Politics, 17/1, pp. 23-40. http://dx.doi.org/10.1080/13629395.2012.655044

DESRUES, Thierry (2013a): "Mobilizations in a hybrid regime: The 20th February Movement and the Moroccan regime", Current Sociology, 61/4, pp. 409-423.

http://dx.doi.org/10.1177/0011392113479742

DESRUES Thierry and KIRHLANI Said (2013b): “Activism under authoritarianism: young political militants in Meknes", The Journal of North African Studies, 18/5, pp. 753-767. http://dx.doi.org/10.1080/13629387.2013.849892

ESPOSITO, John L. (2011): "Arab youth want democracy, not theocracy", CNN, http://edition.cnn.com/2011/OPINION/02/28/protests.democracy.islam/ [Consulted 18 September 2015].

HOFFMAN, Michael and AMANEY, Jamal (2012): 'The Youth and the Arab Spring: Cohort Differences and Similarities', Middle East Law and Governance, 4 (2012) 168-188, http://mthoffma.mycpanel.princeton.edu/Hoffman_Jamal_MELG.pdf [Consulted 13 November 2015].

KNICKMEYER, Ellen (2011): “The Arab World's Youth Army", Foreign Policy, 27 January 2011, http://foreignpolicy.com/2011/01/27/the-arab-worlds-youth-army-2/ [Consulted 12 September 2015].

LIM, Merlyna (2012): “Clicks, Cabs, and Coffee Houses: Social Media and Oppositional Movements in Egypt, 2004-2011", Journal of Communication, 62, pp. 231-248.

http://dx.doi.org/10.1111/j.1460-2466.2012.01628.x

MARCUS, Ben (2013): "Youth Movements in Egypt, Harvard Divinity School, Religious Literacy Project" ", http://rlp.hds.harvard.edu/faq/youth-movements-egypt [Consulted 15 August 2015]. 
MIRKIN, Barry (2013): “Arab Spring: Demographics in a region in transition", Arab Human Development Report Research Paper Series, United Nations Development Programme, [TOWN?], Regional Bureau for Arab States, http://www.arabhdr.org/publications/other/ahdrps/AHDR\%20ENG\%20Arab\%20Spring\%20Mirkinv3.pdf [Consulted 12 August 2015].

MONSHIPOURI, Mahmood (2014): “Tahrir's Legacy: Opportunities and Hazards for the future of youth, movements in the Middle East", Georgetown Journal of International Affairs, http://journal.georgetown.edu/tahrirs-legacy-opportunities-and-hazards-for-the-future-of-youthmovements-in-the-middle-east/ [Consulted 12 August 2015].

MURPHY, Emma (2012): "Problematizing Arab Youth: Generational Narratives of Systemic Failure", Mediterranean Politics, 17/1, pp. 5-22.

http://dx.doi.org/10.1080/13629395.2012.655043

NABULSI, Jawad (2013): "Egypt: Political Challenges for the Youth Movement", Middle East Program, https://www.wilsoncenter.org/event/egypt-political-challenges-for-the-youthmovement

RAPHAELI, Nimrod (February 102006): "Unemployment in the Middle East - Causes and Consequences" in Inquiry \& Analysis Series Report, No. 265, http://www.memri.org/report/en/print1606.htm [Consulted 16 September 2015].

SUGITA, Seiko (2011): Arab Youth: Civic Engagement \& Economic Participation, UNESCO Regional Bureau for Education in the Arab States, Beirut, http://www.unesco.org/new/fileadmin/MULTIMEDIA/FIELD/Beirut/pdf/YCE\%20_EN.pdf [Consulted 14 October 2015].

SCHWARTZ, Stéphanie (2011): 'Youth and the "Arab Spring", United States Institute of Peace, http://www.usip.org/publications/youth-and-the-arab-spring [Consulted 13 September 2015].

UYSAL, Ayşen (décembre 2014) : “Doctrine du maintien de l'ordre et encadrement policier des manifestations en Turquie", Revista de Estudios Internacionales Mediterráneos (REIM), 17, pp. 332. https://revistas.uam.es/index.php/reim/article/view/941/929.

WORLD BANK (2010): Egypt, Arab Rep. [Data file] Retrieved from http://data.worldbank.org/country/egypt-arab-republic [Consulted 15 October 2015]. 